\title{
Creating and Protecting Paths: Learning in an Entrepreneurial State
}

\author{
Knut Sogner
}

This paper discusses how a Norwegian entrepreneurial state has performed over more than seventy years, based on an analysis of state involvement in Kongsberg Våpenfabrikk/the Kongsberg Group from 1945 and to 2015. Mariana Mazzucato has argued that bold technological investments by the state has long-term beneficial effects. The development of the Kongsberg companies adds nuance to this picture. On the one hand, the defense company Kongsberg Våpenfabrikk failed as a company in 1987 and was unbundled into a number of new companies independent of one another. On the other hand, some of the successor companies have been very successful, both in the oil and gas sector and within defense. Taking the defense and oil and gas company the Kongsberg Group as a case, this paper argues that a new style of entrepreneurial state developed in the 1990s and that it proved very successful. The old entrepreneurial state was heavy-handed, bold, and very long-term in its aims; the new entrepreneurial state was cautious, many-headed, and worked through the management of the company. The new entrepreneurial state combined state ownership, stock listing, and procurement considerations and was supported by both the Ministry of Industry and the Ministry of Defense. This new governance structure facilitated a stable corporation that over time integrated other Norwegian maritime electronics companies, which themselves had a checkered history under the old entrepreneurial state. A new corporate governance regime emerged and managed both to protect old and established product lines and to facilitate innovation both in defense and maritime electronics.

Keywords: state ownership, corporate governance, industrial policy

The “Thirty Glorious Years” of 1945-1975 of European and North American prosperity have generally been interpreted as a singular historical circumstance. ${ }^{1}$ The economic crisis and stagnation of the 1970s led most nations to economic reform. The heavy state involvement-

1. I have borrowed the phrase from Foreman-Peck, "European Industrial," See also Grabas and Nützenadel, Industrial Policy in Europe After 1945.

() The Author(s), 2021. Published by Cambridge University Press on behalf of the Business History Conference. All rights reserved. This is an Open Access article, distributed under the terms of the Creative Commons Attribution licence (https://creativecommons.org/licenses/by/4.0/), which permits unrestricted re-use, distribution, and reproduction in any medium, provided the original work is properly cited. 
through Keynesian macroeconomics, a broad strain of industrial policies that included heavy defense spending - was rapidly replaced in the next decade by state retraction from both macroeconomic measures and detailed planning initiatives. Yet recent academic and political reflections have asked whether there is more to learn from the pre-1980 role of an entrepreneurial state and its longer-term consequences. ${ }^{2}$

Chief among those who call for a renewed role for the state is Italian economist Mariana Mazzucato, notably through her book The Entrepreneurial State. ${ }^{3}$ She supports her argument with extensive literature on the positive outcome of state-private interactions. Private business has benefited from a range of state activities. ${ }^{4}$ U.S. federal spending on medicine, defense, and electronics is seen by Mazzucato as a foundation for the successful American pharmaceutical and biotech industry, as well as the flourishing IT sector of Silicon Valley. She places particular emphasis on advanced, large-scale state investments in technology. Over time, these have deep implications for economic wealth creation. Although she acknowledges private-state interaction, she is particularly forthright about how the state can be active, constructive, and bold.

Norway is an interesting case to discuss what role an entrepreneurial state may play. Norway fits into the larger post-1945 European framework of Keynesian economic policies, state ownership of key enterprises, and indicative planning measures alongside technologically ambitious defense spending that from very early on also had an industrial aim. ${ }^{5}$ The case of state-owned military industrial firm, Kongsberg Våpenfabrikk, is emblematic. After failing commercially in the 1980s, it was unbundled in a privatization process in 1987 that turned out to be very successful in the long run. ${ }^{6}$ It is seemingly evidence that Mazzucato could be onto something that also applies to small nation-states with open economies.

This paper discusses the experience of the entrepreneurial Norwegian state in the Kongsberg case. The first part gives the broader Kongsberg-Norwegian background to the larger Western story of the period after 1945 and the subsequent turn to market measures in the 1980s. This explains the company's failure as overstretch. The next part asks whether the post-1987 development of the new Kongsberg agglomeration-building, just like Silicon Valley, on digital technology sourced from the military—can be explained by positive interactions and spillovers, similar to what some scholars suggest explains the success of Silicon Valley. The answer to that is a "no," which leads to the third and final part: the introduction of a new style, a more subtle variant of the successful "entrepreneurial state," one that is different from the interventionhappy state propagated by Mazzucato. This part follows the company the Kongsberg Group, a private stock-listed defense-based company that the state has owned 50.1 percent of since 1993.

\section{The Entrepreneurial State, 1946-1987}

By and large, Norwegian economic and industrial postwar policy follow the European pattern of Keynesian macroeconomic financial steering with a range of measures to increase industrial

2. See, e.g., the introduction in McCloskey and Mingardi, The Myth.

3. Mazzucato, The Entrepreneurial State.

4. Fagerberg, Mowery, and Nelson, The Oxford Handbook.

5. On indicative planning, see Sogner, Fra plan til marked; for a broader exposition, see Hanisch and Lange, Veien til velstand.

6. Øyangen, Moderniseringslokomotivet; Sogner and Petersen, Strategiske samspill. 
production. The Labor government that assumed power in 1945 and held the Storting (the parliament), was not particularly ideological. The solutions chosen may be said to be the result of pragmatism, although with a distinct dose of planning ideology. ${ }^{7}$

Looking in particular at the industrial policy dimension, something akin to "an entrepreneurial state" was hardly visible until around 1960. New state enterprises were built in the 1940s, but really the state filled the void left by the German Occupation effort. ${ }^{8}$ True, new research institutions were rapidly built, very much inspired by the Allied research effort during the war. But the Labor government also aligned with private business, promoting some chosen companies and sectors (shipping, use of energy) through tax concessions and access to cheap energy.

The changes that occurred around 1960 represented an evolution toward bolder measures, albeit within a framework adopted from Europe. One can see Norwegian industrial policy as an adaptation to French "indicative planning."9 The Norwegian approach was less "planned" and not really rooted in the Ministry of Finance. It was, instead, constituted of a range of articulated policy goals that created some kind of advantage for those companies willing to fulfill the state goals. These included locating in Norway for the international aluminum industry, locating or expanding in Norwegian rural areas in general, finding markets abroad for national producers, the financing of mergers, and financing of development processes.

This industrial policy framework deserves to be called "an entrepreneurial state," because it contained state entrepreneurs that acted far beyond a passive and restrained indicative policy. Chief among them was Erik Brofoss, minister of finance from 1945, head of the National Bank of Norway for many years, and a man with articulated ideas about how to develop internationally competitive business. ${ }^{10}$ In ten years, from 1960 onward, he had a coordinating role in state funds in support of some of the abovementioned priorities. Kongsberg Våpenfabrikk and electronics company Simrad (see below) were recipients of several grants from one of these funds. Another important “entrepreneur” was United Nations' first general secretary, Trygve Lie, who around 1960 worked to induce the international aluminum industry to establish production in Norway. But the Norwegian entrepreneurial state was also an arena for state and private initiatives. Brofoss, for one, was not above making well-informed suggestions to private companies that had contacted the state. In the long rise of weapon manufacturer Kongsberg Våpenfabrikk as a high-tech company, another set of state entrepreneurs with a footing in science and technology played a crucial part.

Over more than four decades, Jens Chr. Hauge, Finn Lied, and Fredrik Møller contributed in various roles to the modernization of Kongsberg Våpenfabrikk. ${ }^{11}$ Until the mid-1950s, this was an old-fashioned, state-owned weapons' manufacturer. It made firearms and old-fashioned rockets, and for obvious reasons, the German Occupation had not hastened its modernization. Hauge was the leader of the Resistance in Norway at the end of the war and minister of defense

7. Lange, "Førsteopponentinnlegg."

8. The state did establish a state-owned iron works, but this was based on collaboration with private companies.

9. Sogner, Fra plan til marked. See also Sogner, "The Rise and Fall."

10. Sogner, Fra plan til marked. skning.

11. Njølstad and Wicken, Kunnskap som våpen; Njølstad and Institutt for energiteknikk, Strålende for- 
between 1945 and 1951. He played a pivotal role in the creation of both the Norwegian Defense Research Establishment (NDRE) in 1946 and the Institute for Atomic Energy two years later. Fredrik Møller and Finn Lied were consecutive heads of the NDRE from its inception to the 1980s. Both had important roles within the Norwegian atomic energy sector. Both research organizations were preoccupied with commercialization of science and technology, and Kongsberg Våpenfabrikk was in receipt of new defense products-missiles, command control systems, air-defense systems-for decades. Hauge and Møller were part of Kongsberg Våpenfabrikk's board of directors for decades. They collaborated with Bjarne Hurlen, CEO at Kongsberg Våpenfabrikk from the 1950s to the end of the 1970s.

At its very start, in the mid-1950s, modernization of the company was cautious. ${ }^{12}$ The company and its political friends used the political economy of Nordic collaboration to start production of car parts, as did state-owned ammunition company Raufoss. Missiles were produced on license from the United States. Gradually, Kongsberg commercialized products developed elsewhere, primarily from NDRE. An important argument behind the modernization of Kongsberg Våpenfabrikk was that the company could play the role of a national industrial lever, or "locomotive," with positive industrial externalities. ${ }^{13}$ This was obviously induced by the research optimism of the time. It was also inspired by Sweden's superior industrial development compared with Norway, as well as Sweden's prioritization of a national defense industry that would further support industry in general.

Kongsberg Våpenfabrikk was not the only recipient of the modernization policy. One of the most successful diffusions from NDRE concerned echo sounders and sonars. Developed for naval purposes, these were redesigned for fishing activities by the private corporation Simrad, which was allowed to use NDRE constructed prototypes. ${ }^{14}$ Commercializing atomic competence was more difficult, but in 1957, Fredrik Møller became CEO of a company with that purpose, Noratom. Kongsberg Våpenfabrikk, Raufoss Ammunisjonsfabrikk, and Norsk Hydro (partly state owned) were major shareholders. ${ }^{15}$ In 1965, Noratom, Kongsberg Våpenfabrikk, and Norsk Hydro established Norcontrol to develop and make products to introduce automation solutions for the huge Norwegian maritime fleet. ${ }^{16}$ This was a deliberate attempt to connect technology to a large national business market, and it involved several Norwegian shipowners. When oil and gas was discovered in the North Sea, it was Finn Lied, as minister of industry, who designed a state-owned Norwegian company to take a place in the midst of the oil sector. The first chairman of the board of Statoil was Jens Chr. Hauge, soon to be replaced by Lied himself; he held this position until 1984. Statoil's first CEO was secretary to Lied in the Ministry of Industry, and key positions in the company were taken by people with a background in the Institute for Atomic Energy. Lied saw his own and Statoil's roles as facilitators of Norwegian oil and gas technology, and he worked to steer the Statoil organization in this direction. ${ }^{17}$

12. Øyangen, Moderniseringslokomotivet.

13. Wicken, Wicken, "Vekst og våpen."

14. Sogner, God på bunnen.

15. Nilsen, "Forsøket på å skape."

16. Overby, "Etableringen."

17. Sogner, God på bunnen, $171 \mathrm{ff}$. 
During the 1970s and 1980s, Kongsberg Våpenfabrikk benefited from the opportunities in the Norwegian part of the North Sea. Kongsberg established the company Albatross for production of a "dynamic positioning" device that could measure all the forces impacting a vessel (wind, waves, currents) and keep the vessel stable (or steer it) by adjusting its propellers and thrusters. This was a collaborative task with Simrad, which provided a hydroacoustic system for positioning the vessel against a fixed point at the bottom of the sea. ${ }^{18}$ Subsequently, Albatross also developed a highly sophisticated system integrator that could be used to automate and steer entire oil platforms. Both these products used highly sophisticated information technology. Kongsberg Våpenfabrikk also started to develop underwater production systems to replace platforms. This was also a very complicated technical task that depended on pipeline technology. This technology was sourced from the Institute of Atomic Energy and commercialized by companies other than Kongsberg. Another Kongsberg product was seismic technology for explorations under the sea bottom. The 1970s was a time of great expansion for Kongsberg Våpenfabrikk.

Several of its military projects were up and running as salable and, in some cases, exportable products. The naval missile Penguin, originally developed by NDRE, was particularly noteworthy. Kongsberg Våpenfabrikk invested heavily in production facilities to supply airplane parts to the NATO F-16 jet project. The company also developed and sold gas turbines and car parts. Its North Sea activities absorbed resources, and when the OPEC-induced crisis hit the international merchant marine business in the mid-1970s, Kongsberg Våpenfabrikk stepped in and acquired crisis-ridden Norcontrol, the abovementioned producer of advanced IT equipment to the global shipping fleet. Kongsberg Våpenfabrikk had a strong position in Norwegian political circles. Board member Jens Chr. Hauge was an efficient spokesperson, and the company found it quite easy to refinance several times during the 1970s and 1980s expansion. The Norwegian state (government and parliament) was particularly generous with financial help to industry in crisis in the mid- to late 1970s, not least to protect national champions. This changed in the late 1970s, a time of sudden state restraint, remorse, and a turn to the market. Kongsberg Våpenfabrikk escaped the political showdown relatively unscathed, for several reasons. It represented investment in high technology, it had an important role for Norwegian defense, and it was active in the prioritized niche of the time, the growing oil and gas sector.

The collapse in oil prices and the crash of global stock markets in 1986 put an end to Kongsberg Våpenfabrikk's continued rise. By 1987, it was clear that the company was either bankrupt or moving quickly in that direction. The group of modernizing architects who had helped create the high-tech company realized that this situation required and warranted yet another injection of capital. Jens Chr. Hauge, Finn Lied, and Tor Aspengren (former head of the national employment union) took it upon themselves to make the case to Prime Minister Gro Harlem Brundtland. ${ }^{19}$ Kongsberg Våpenfabrikk had to continue, for Norway’s sake. They argued that the company had a university research culture of great industrial value. ${ }^{20}$ Brundtland and Minister of Industry Finn Kristensen did not back down: The losses were too great

18. Ibid.

19. Njølstad, Jens Chr. Hauge, $673 \mathrm{ff}$.

20. Sogner, En liten brikke $i$ et stort spill. 
and had gone on for too long a time. Another business model had to be applied for the Kongsberg industry to succeed in the future.

Kongsberg Våpenfabrikk was rapidly reorganized. The company itself went into receivership. Some businesses were integrated into other companies, like Albatross, which was sold to Simrad; and several new companies were created from scratch. Some of these startups deserve a mention: Siemens founded Kongsberg Offshore Systems for underwater oil production (today known as TechnipFMC); a group of managers founded Kongsberg Automotive; Volvo created Volvo Aero (for F-16 products); and in 1987, the state re-created a specialized and 100 percent state-owned defense company, initially called Norsk Forsvarsteknologi, and later the Kongsberg Group, to continue the original defense business.

This reorganization of Kongsberg Våpenfabrikk proved to be a huge and rapid success. Almost all the new companies turned profitable within a year. In his book about Kongsberg Våpenfabrikk between 1945 and 1987, Knut Øyangen argues that this success reflected a shift from "soft budget constraints" to normal profit seeking. ${ }^{21}$ The company had been characterized by a governance consensus that relied on the probability of getting a capital injection and therefore facilitated bold technology- and capital-demanding projects extending the company's scope. Once there were budget constraints, the businesses could turn profitable through rationalization. Øyangen also argues that the pre-1987 governance consensus was rooted at the corporate and state-institutional level. He portrays Jens Chr. Hauge, Finn Lied, and others as politically savvy users of state opportunities. In this reading, the modernization of Kongsberg Våpenfabrikk was not part of a grand national plan. Øyangen is also very sympathetic to what they actually achieved in giving engineers the opportunity to develop internationally competitive competence.

Øyangen does not, however, explain the remarkable longer-term development of the Kongsberg Group, even if the turn to profitability was rapid and the Kongsberg Group to a great degree followed technological and product paths from the past. The post-1987 changes are puzzling and need further explanation. As late as 2008, the company's turnover in the original defense sector-missiles and command-control systems-in real terms was almost exactly at the same level as in 1988. What was gained in terms of turnover from selling new defense products was lost in turnover from products that had been discontinued. As Table 1 shows, the solid rise in turnover in the period was primarily a result of the purchase of the maritime electronics companies Norcontrol (1992), Simrad (1996), and Navia (2000). The development and sales of Protector, a weapon station and a concept that also originated outside the Kongsberg Group, also contributed to the rise in turnover after 2000. Moreover, the post-2005 rise in turnover coincided with increased profitability. From 2005 until 2013, turnover in fixed prices increased by a factor of 2.3, almost all due to organic growth. Profit margins rose from about 5 percent to 9.6 percent of turnover in 2007 and afterward stayed above 10 percent.

The story behind these numbers is that the profitability possibilities hidden within Kongsberg Våpenfabrikk were quite limited. Even when the post-1987 leadership in the Kongsberg Group pursued profitability and achieved profits, these profits were fairly mundane. There was little room for increased investment in research and development. Even if the company

\section{1. Øyangen, Moderniseringslokomotivet.}


Table 1. Key figures in fixed prices, the Kongsberg Group 1988-2013

\begin{tabular}{|c|c|c|c|c|c|}
\hline & Turnover & Maritime & Defense & Weapon station & Event \\
\hline 1988 & 1783 & & 1609 & & \\
\hline 1992 & 2321 & 609 & 1646 & & Norcontrol (purchase) \\
\hline 1996 & 3172 & 1769 & 1398 & & Simrad (purchase) \\
\hline 1998 & 4404 & 2790 & 1605 & & \\
\hline 2000 & 5020 & 2827 & 1842 & & \\
\hline 2001 & 5682 & 3329 & 2197 & & Navia (purchase) \\
\hline 2005 & 5031 & 2636 & $2302^{a}$ & & \\
\hline 2006 & 5709 & 3019 & $2546^{a}$ & & \\
\hline 2007 & 7003 & 4089 & 1760 & 1055 & \\
\hline 2008 & 8981 & 4897 & 1669 & 1949 & \\
\hline 2009 & 10,991 & 5296 & 2175 & 3280 & \\
\hline 2010 & 12,032 & 4880 & 2621 & 4412 & \\
\hline 2011 & 11,601 & 5133 & 2987 & 3219 & \\
\hline 2012 & 11,912 & 5696 & 3542 & 2189 & \\
\hline 2013 & 12,163 & 6158 & 3393 & 1803 & \\
\hline
\end{tabular}

${ }^{\text {a }}$ Weapon station included.

Source: The Kongsberg Group. The numbers are in million Norwegian kroner. The index is the consumer price index of Statistics Norway, $1998=100$.

did put money into new product development, great results were achieved only after 2005. With respect to possible profitability levels, the situation the new company inherited from the old one was not great. For Kongsberg Våpenfabrikk to achieve its research ambitions, it had covered costs through overuse of resources. This led to the 1987 reorganization.

How can the Kongsberg Group's intensified success after 2005 be explained? Or, to put the question more in line with the direction of this paper, to what extent do the Norwegian state's policies matter-if at all-in understanding of that success? The state in 2021 remains the majority owner of the Kongsberg Group, which is today more diversified than in 1987. It has added other Norwegian companies that previously benefited from Norwegian industrial policies. The following examines possible causes of this success in two separate parts. Eventually, the role of the state will be discussed later. First, the agglomeration hypothesis is discussed: One of the underlying ideas of the modernization of Kongsberg Våpenfabrikk was the idea that it would have a spillover impact on Norwegian industry in general. This argument was repeated in 1987 to keep the company going as a bundled unit. But the unbundling seemingly unleashed creativity that could be ascribed to a new local Kongsberg town dynamic after the reorganization into different companies. From 1987 onward, Kongsberg could be viewed as a Silicon Valley in miniature.

\section{The Agglomeration Hypothesis Rejected}

There is very little evidence of benefits from significant spillovers or something akin to "a Kongsberg cluster” after 1987. ${ }^{22}$ The new companies coming out of the defunct Kongsberg 
Våpenfabrikk all operated in different industries with divergent technology bases. This was no cluster, according to Michael Porter's definition as a group of firms operating in the same business, benefiting from common supportive organizations, and spurred on by rivalry. Few, if any, companies served the agglomeration in any way that was important for product development. ${ }^{23}$ There was also indeed surprisingly little local business interaction going on, at least in the first fifteen years. ${ }^{24}$ There is simply no significant marketplace within the Kongsberg agglomeration. In a study of 2002, it was found that the foreign-owned companies had more contact with their foreign headquarters than other Kongsberg companies of Kongsberg. Moreover, the companies were relatively stable: People stayed, and they very rarely left to start new ventures.

One of the distinguishing features of the Kongsberg agglomeration is that it is a collection of end producers. There are no component makers, although there are Norwegian IT component makers outside Kongsberg that deliver to some of the Kongsberg companies, including the Kongsberg Group. That the collection of Kongsberg companies are all end producers was the result of the effort to keep the industry alive during the crisis in 1987. The new companies became end producers by default. They were divided into separate companies in accordance with their sales possibilities, forcing them to focus on commercial markets. This reorientation was deliberate, intended to take into account the advent of the computer and other advanced components as purchasable commodities. The Kongsberg companies sell internationally, and they source components internationally. The IT companies of Kongsberg have benefited enormously from the IT industry's growing vertical specialization.

On a practical level, the Kongsberg Group has been "landlord" of much of the Kongsberg industry ever since the 1987 reorganization. It continued its predecessor's ownership of the business park where all the original buildings and factories were located. There has been a lot of interaction between the Kongsberg companies, but of a more indirect and practical type. ${ }^{25}$ They share a government-funded National Center of Expertise in systems engineering, though that is probably more a consequence of political opportunity for funding and outside recognition than a logical outcome of business considerations. They collaborate about common interests like education and infrastructure. There is, of course, a common labor market. Kongsberg is full of engineers-and some of them do change jobs. Kongsberg is a great place to run an IT company, and the knowledge exchange between the engineers as private citizens should not be underestimated.

The Kongsberg agglomeration seems to match Steven Klepper's findings. He compared the experience of the emergence of the car industry in Detroit with the development of Silicon Valley and found that agglomeration effects are exaggerated. ${ }^{26}$ Spinoffs usually locate close to the original companies. If they succeed, it is because of their business plans and their competence at the outset. That they locate their businesses in the same area as the original company is just coincidental and creates something of an illusion of an agglomeration advantage. Klepper's interpretation fits the Kongsberg agglomeration perfectly. The companies

23. Ibid.

24. Isaksen, "Innovation Dynamics."

25. Reve and Jakobsen, Et verdiskapende Norge, 44.

26. Klepper, "The Origin and Growth." 
following in the wake of Kongsberg Våpenfabrikk were successful, yet it is very difficult to identify any agglomeration effect of significance. To use Klepper's vocabulary, much of their success seems hereditary. They had an initial advantage because of their foundation within Kongsberg Våpenfabrikk, but the explanation for their continued success must be found elsewhere.

Klepper's analysis fits much better than AnnaLee Saxenian's comparison of Silicon Valley in California to Route 128 outside Boston, a computer technology hub. She finds that Silicon Valley was able to ride out the crisis of the 1980s because it was a networked culture operating on many levels and penetrating almost all that went on-much of it of it in an informal way. The companies benefited from a large flow of information. This made them current, flexible, and internationally competitive. ${ }^{27}$ Route 128 , on the other hand, which had similar technological advantages to Silicon Valley, had huge problems. So did Kongsberg Våpenfabrikk, yet the subsequent successful Kongsberg agglomeration never developed anything approaching Saxenian's networked economy.

Silicon Valley is an IT hub of vastly greater proportion than Kongsberg, but the two do have some common features. Both have been heavily influenced by military investments in research and development since World War II. Systems engineering is a common root, as is computer technology in various forms. Kongsberg Våpenfabrikk, the sole technology company of Kongsberg until 1987, built its digital technological base mainly on technology transfer from the NDRE. ${ }^{28}$ Kongsberg Våpenfabrikk benefited from national knowledge transfer around several new and advanced products. This is comparable to Stuart Leslie's claims about how American IT companies benefited from American universities on the West and East Coasts. ${ }^{29}$ NDRE also had links with American academic institutions since the 1940s. It may be said to have combined the role of a university and a product-oriented research institution benefiting Kongsberg Våpenfabrikk in particular. ${ }^{30}$ This benefit was not linked to mere transfer of knowledge; a number of engineers left the NDRE to work for Kongsberg Våpenfabrikk.

Kongsberg Våpenfabrikk was itself an arena for knowledge sharing. In Making Silicon Valley, Christophe Lécuyer presents a broad and technology-informed interpretation that underlines the importance of long-term developments in Silicon Valley. ${ }^{31}$ This is a traditional argument for the advantages of having similar companies located in the same region. He provides a very thorough narrative of how Silicon Valley came to be, and how the coming of semiconductor production and innovation was only a part of a long story that started with radio components. The emerging variety of technologies and capabilities within Silicon Valley supported each other. Kongsberg, though much smaller, may have had a similar starting point, but until 1987, all knowledge sharing took place within one hierarchical corporation. Over time, Kongsberg Våpenfabrikk became an increasingly complex

27. Saxenian, Regional Advantage.

28. Njølstad and Wicken, Kunnskap som våpen; Øyangen, Moderniseringslokomotivet.

29. Leslie, The Cold War and American Science.

30. Olav Wicken has written about this in several places, but see Wicken, Norske våpen til Natos forsvar.

31. Lécuyer, Making Silicon Valley. 
technologies company, and the internal dynamic must have positively impacted the broader innovative capacity that came into play after $1987 .{ }^{32}$

Martin Kenney and Urs von Burg argue that a core cause of Silicon Valley's long-term success is its technological trajectory within semiconductors. ${ }^{33}$ Route 128 was at a disadvantage as regards technology compared with Silicon Valley, because it depended heavily on the rise of the minicomputer. When the personal computer arrived, Route 128 companies had difficulty changing. As a group, they had a comparatively narrow set of competences, and a crisis ensued. Silicon Valley, on the other hand, had a much broader competence base. Its core root in semiconductors-used in minicomputers, personal computers, and a host of new digital products—enabled a remarkably resilient response to shifts in demand.

Kongsberg Våpenfabrikk had a fairly broad competence base in the 1980s and did establish many product and technical trajectories. The Kongsberg companies subsequently exploited trajectories stemming from Kongsberg Våpenfabrikk. Each company constructed in 1987 was based on one or more such platforms from the previous company. The Kongsberg agglomeration-with the possible exception of systems engineering-does not have a common technological denominator, such as semiconductors. But it has a number of companies with deep technical traditions that have been exposed to market considerations. In the next section, this paper turns to the trajectories contained within the Kongsberg Group after 1987: The most important of these are command control systems, systems integration, sonar/hydroacoustics, positioning equipment, surveillance products, missiles, and air-defense systems,

To sum up this section, systems engineering might be a more important common denominator in Kongsberg than is argued here. Informal diffusion of IT knowledge between companies and people in Kongsberg may also be unaccounted for. But even if this is the case, they still do not explain the dramatic success of the Kongsberg Group in international markets. The Kongsberg Group continued as a national and private company, partly owned by the state, and exploiting national opportunities in defense, shipping, and oil and gas. The argument that follows is that the Kongsberg Group has benefited through the learning that has been going on within the Norwegian entrepreneurial state.

\section{The Kongsberg Learning Experience}

The post-1987 leadership of the Kongsberg Group prioritized following old paths, but this was not because they thought it was clever. Following these paths seemed a necessity for a constrained company. It also seemed logical for a company that had a heritage as a big spender. There was not much to be excited about with the new company, although the turn to profitability in 1988 was obviously a good sign. Several factors contributed to the longer-term success. One was the rebirth of an entrepreneurial state of a different kind than before.

In the preceding discussion, the concept of a Norwegian entrepreneurial state was discussed on two levels: (1) attempted and realized industrial policy ideals, decisions taken, and

32. In the book about Kongsberg Våpenfabrikk from 1945 to 1987, such a hypothesis is not tested. Øyangen, Moderniseringslokomotivet.

33. Kenney and Burg, “Technology, Entrepreneurship and Path Dependence.” 
paths explored; and (2) an arena, an institutional structure that facilitated or permitted certain kind of actions from politicians as well as companies. Both levels are relevant in the following discussion.

A striking element in the period after 1987 is the clarification of roles. Previously, actors like Jens Chr. Hauge and Finn Lied moved between the positions of ministers in governments, directors of state agencies, member of boards, and self-proclaimed lobbyists, to mention the most obvious. This was no longer the case after 1987. Roles became more distinct, and superficially one could get the impression that the entrepreneurial state was dead and gone. The world, too, had moved on. The European Union (EU) established a single market that Norway joined in 1994 through the European Economic Area (EEA) agreement, which severely limited how state policies could favor national companies. The Cold War came to an end in the years around 1990, impacting both defense spending and the strategic role of defense in nation-states and creating an impression that the world at large was moving toward some sort of liberal market economy.

The end of the Cold War was the Kongsberg Group's main challenge in its first five years of existence. Jan T. Jørgensen, CEO of the Kongsberg Group since 1987, believed the fall of the Iron Curtain in 1989-1991 would mean drastic cuts in defense spending; he could not foresee a future for the Kongsberg Group as purely a defense company. ${ }^{34}$ Nor could he see that the state - which since the 1970s had drawn back from prioritizing companies-would be willing to develop the Kongsberg Group in any other direction than purely as a defense company. Being a defense company had legitimized its continuation as a state-owned company in the restructuring in 1987. Jørgensen therefore asked the Ministry of Industry to list the Kongsberg Group on the stock exchange in order to acquire fresh capital. In 1992, he had already acquired Norcontrol, previously owned by Kongsberg Våpenfabrikk, in order to diversify into maritime electronics. The ministry agreed, and the Kongsberg Group was stock listed in 1993 with 50.1 percent state capital and 49.9 percent private capital.

Jørgensen's choice of privatization model followed a particular Norwegian pattern. He was inspired by state-owned Raufoss, which had undertaken a similar maneuver in 1990, with the state keeping 53.3 percent of the stock-listed company. In principle, what happened was 100 percent privatization, in the sense that a state-owned company became a private and public company with the ensuing rules and regulations. That the state continues to own a large part of the shares is called "the Hydro model" and is a Norwegian peculiarity. ${ }^{35}$ The Hydro model had been created by accident, following the state confiscation of German shares in Norsk Hydro after World War II. In the 1980s, it was seen as a successful way of combining national control and profitability-seeking solutions-more so than the fully owned state enterprises. It emerged as an interesting solution due to various crises and challenges in the 1980s, not least the oil price collapse from 1986. Keeping significant state ownership within the framework of private corporations also foreshadowed the new and much more restrictive trade policies against national prioritization that followed Norway's adaptation to the EU through the EEA agreement. The use of the Hydro model is obviously a sign of reform-not

34. Interviews with Jan T. Jørgensen, April 9, 1997, and Morten Kallevig (high-ranking civil servant in the Ministry of Industry), April 21, 2014.

35. Lie, "Context and Contingency." See also Christensen, "Statlig eierskap." 
retraction-of the Norwegian entrepreneurial state. This adaptation of the entrepreneurial state is foreign to Mazzucato's perspective.

Interestingly and significantly, the application of the use of the Hydro model was pushed by the corporations—not politicians. It was the Raufoss's management in 1989, in agreement with its unions, that suggested the application of the Hydro model. The Labor government of the time had made several other proposals to solve Raufoss's problems, ranging from full privatization to integration with the Kongsberg Group or with other state enterprises. ${ }^{36}$ The incoming Conservative government accepted Raufoss's proposal. When the same Labor government had reorganized Kongsberg Våpenfabrikk in 1987, it only opted for clean solutions: full privatization of most of the businesses and full state ownership of the Kongsberg Group. Both the Raufoss and the Kongsberg cases illustrate that the introduction of the Hydro model as a political tool in the years around 1990 is tightly connected with managerial initiative and purpose. That does not make the transition any less political and significant. The viability of this option in the eyes of politicians lies in their trust in the ability and integrity of company management. In the Norwegian political climate, that also means the management has to have the trust of the unions. Both Kongsberg and Raufoss are long-established industrial production sites with strong unions. The emergence and adaptation of the Hydro model is an outcome of balancing several interested parties and complex historical processes. It was not only a choice of governance model, but also a contract about the rules of the game. It signified that establishing "an entrepreneurial state" may not only be a choice of ideologically conscious politicians, but also a reflection of deep-seated societal structures.

For the governance of the Kongsberg Group, the ownership model has introduced stability and a long-term horizon. There has been remarkable stability in the company's leadership. Three positions-CEO of the Kongsberg Group, head of the defense division, and head of the maritime business - have been shared by only five different people in the 21 years from 1993 until 2014. There have been three different CEOs, and the stability of the two divisions has been even greater. The planning horizon has been long, not least within defense, where one person was in charge all along. This stable group of senior managers has been well positioned to utilize established networks of communication and influence, in particular in the Norwegian defense sector and in Norwegian oil, gas, and shipping sectors.

The biggest difference in orientation between the new post-1987 Kongsberg Group and its predecessor was the shift to utilize already established product paths. The Kongsberg Group has continued in established defense product paths, and even the new addition-a weapon station-existed as product when it became part of the Kongsberg Group. While Kongsberg Våpenfabrikk had diversified primarily by adding research projects coming from the outside, the Kongsberg Group acquired companies with their product portfolios and continued to explore these existing paths, many which had their root in the mixed economy of the Norwegian entrepreneurial state before 1987.

In the process, the Kongsberg Group became a maritime electronics company. In 1996, Simrad was added to the 1992 purchase of Norcontrol. In 2000, the Kongsberg Group acquired Navia, a smaller company that produced ship control systems. The Norwegian maritime sector

36. Wang, RA i skuddlinja, 301-305. 
is huge, spanning the merchant marine, fishing, cruising, oil and gas, and fish farming. Norcontrol made automation systems for the merchant marine. Simrad specialized originally in hydroacoustic products for fish locating, seabed mapping (financed by Statoil), and naval applications. It had added Albatross when Kongsberg Våpenfabrikk disintegrated in 1987. Simrad was stock listed and was of the same size as the Kongsberg Group. Since 1985, Finn Lied had been chairman of the board. This new and significant maritime arm has been called Kongsberg Maritime since 1997. It represented geographic expansion into Horten (Norcontrol and Simrad), less than an hour's drive away from Kongsberg. Navia was located in Trondheim, a seven-hour drive and also home to the Norwegian University of Science and Technology.

In addition to the long-term stability given by state ownership, Kongberg Maritime benefited from the longer-term implications of the pre-1987 entrepreneurial state. The collapse of oil prices in 1986 scared away some of the big international oil companies that had explored Norwegian oil opportunities through older rig technology. ${ }^{37}$ New Norwegian technology, usually financed by the state in the 1970s and 1980s, and with Statoil as an important actor, filled this gap. In the cost-cutting 1990s, Norwegian solutions were able to create new and cheaper production possibilities through underwater production or floating vessels. Simrad (seabed mapping) and Simrad Albatross (dynamic positioning and system steering), together with another Kongsberg company (Kongsberg Offshore Systems/TechnipFMC), met some of the need for change. ${ }^{38}$ Of course, the Norwegian parties on the market-creating sidethe ministry and the large oil producers Statoil and Hydro-knew that Norwegian suppliers could fulfill their demand for new and cheaper production systems.

Kongsberg Maritime has subsequently consolidated its strategy and product development under the umbrella slogan of "the full picture," bundling products physically and emphasizing sales of packages of products. The idea was to take Kongsberg Maritime from making a number of individual "boxes" to providing integrated solutions packages as one system: sonar, navigation systems, surveillance systems, process control systems, and systems for dynamic positioning, including steering assistance. These packages were sold to various kinds of vessel and oil installations. ${ }^{39}$ In 2003, Kongsberg Maritime reorganized its various entities-stemming from a number of different companies-into one integrated organizational entity to fulfill the goal of achieving "full picture" products. The reorganization coincided with a deliberate expansion into Asian markets (Singapore, South Korea, and China). In this, they followed Norwegian shipping customers, who shifted the building of ships from Norway to new countries in Asia. It was a conscious move to become a market-driven systems provider, albeit a systems provider that had expertise in most of all the constituent parts of the systems.

When it joined the EU's single market through the EEA agreement, Norway could no longer prioritize its own industry. The defense sector remained an exception, though. The Ministry of

37. Ryggvik, "A Short History of the Norwegian Oil Industry”; Engen, Simensen, and Thune, "The Evolving Sectoral Innovation System for Upstream Oil and Gas in Norway.”

38. Ryggvik, "A Short History of the Norwegian Oil Industry”; Engen, Simensen, and Thune, "The Evolving Sectoral Innovation System for Upstream Oil and Gas in Norway.”

39. This is covered in Sogner and Petersen, Strategiske samspill, 171-218. Interviews with Jan Erik Korssjøen (CEO of the Kongsberg Group), May 14, 2013, and Torfinn Kildal (head of Kongsberg Maritime) and Geir Håøy (multiple leadership positions within Kongsberg Maritime), September 26, 2013, have been particularly important. 
Defense in the early 1990s therefore formulated a new agenda for national priorities that had implication for what was by far the largest Norwegian defense company, the Kongsberg Group. ${ }^{40}$ The challenges were the Hydro model and the fact that the company had a civilian arm in maritime electronics. This opened up the possibility of allegations of preferential treatment in the maritime business, a matter that needed to be addressed very thoroughly. The state's shares-managed by the Ministry of Industry—needed to be dealt with passively; communication between the Ministry of Defense and the Ministry of Industry had to be nonexistent. ${ }^{41}$ Out of these changes emerged a practice that became an extension of the Hydro model—almost a Kongsberg model.

While preferential treatment is normal in the defense sector worldwide, the ownership structure of Kongsberg gives this arrangement a twist. This was an arrangement that quite probably emerged as a consequence of separate events interacting. The alignment of corporate strategy, based on prior corporate expertise, and state policies, created a synthesis of effort that proved to perform more forcefully than pure state ownership did in the previous period. The state no longer guides the company but works in support of the company's own activities and preconditions. One arm of the state is passive and creates managerial room. Another arm of the state supports certain corporate activities that may have huge commercial benefits. The two parts of the policy reinforce each other. This double movement-building on the Hydro model —and involving a prepared and "armed" corporate management can be called the Kongsberg extension to the Hydro model.

One of the most successful new developments of the Kongsberg Group is a family of airdefense systems now in its third generation, NOAH, NASAMS I, and NASAMS II. ${ }^{42}$ This product group builds on previous command-control systems and stems from Kongsberg Våpenfabrikk. Originally, the Norwegian Air Force required a flexible network-based air defense with real-time communication, and Kongsberg Våpenfabrikk/the Kongsberg Group developed several generations of systems. Kongsberg emphasized developing only software, purchasing all the hardware like the Amram missile and the radar from its eventual partner Raytheon. Some of the input for the most complicated software came from the NDRE. Although it was already a technical success in the early 1990s, Raytheon only became a partner in 1996, after it was more or less forced to in 1996 by demands from the Norwegian government: If Raytheon were to sell missiles to Norway, it should collaborate with the Kongsberg Group. Gradually, Kongsberg proved to Raytheon that NASAMS is a distinct and valuable product, and the two partners have landed several large contracts over the last ten years. This product group has been developed, tweaked, and marketed for almost forty years, and its huge commercial success did not happen quickly.

Kongsberg has greatly extended its missile competence through state assistance. In 1996, it was granted a huge state development contract for a naval strike missile. The NDRE had

40. Interview with Leif Lindbäck (former director at Ministry of Defense), March 21, 2014.

41. Interview with Leif Lindbäck (former director at Ministry of Defense), March 21, 2014.

42. This story is covered in Sogner and Petersen, Strategiske samspill, 57-60, 99-100, 120-124, $257-263$. Interviews with Leif Lindbäck (former director at Ministry of Defense), March 21, 2014, Henry K. Johansen (former senior engineer of the Norwegian Defense Research Establishment), May 26, 2014, and Harald Ånnestad (head of Kongsberg Air Defense Systems and former research engineer), February 20, 2014, have been particularly important. 
previously provided Kongsberg Våpenfabrikk with several generations of the Penguin missile, originally developed in the 1960s as a missile for use by smallish Norwegian naval vessels operating in narrow Norwegian fjords. ${ }^{43}$ Kongsberg also benefited by hiring some of the most competent missile engineers within the NDRE, laying the groundwork for Kongsberg to be in command of the naval strike missile project. ${ }^{44}$ Securing full responsibility and overall control of such an advanced system development project was not only a landmark, but quite probably of great significance for the general standard of system competence within Kongsberg. Developing this missile was by far the most complex, difficult, and time-consuming of all of the Kongsberg Group's various research and development projects. In the naval strike missile project Kongsberg took a leading role, albeit not without assistance from the NDRE.

The Norwegian government helped Kongsberg to promote an adjustment of the naval strike missile as a joint strike missile, a product to fit the launch of Lockheed Martin's joint strike fighter (F35), the new U.S. and NATO fighter. Again, the long-term approach is noticeable. The naval strike missile dates back a quarter century, and it builds on missile competence going back more than half a century.

Kongsberg's greatest commercial success in defense up until the 2010s, was Protector, a weapon station. Originally developed for the Norwegian Army, it was repurposed in 2000 and 2001 for the U.S. Army. This was a great success, thanks partly to the war on terror and the sudden and unexpected need to protect American soldiers in the field in Afghanistan and Iraq. ${ }^{45}$ Protector was a mass-produced mechanical product, a container with weapons and sensors placed above vehicles to protect the driver. Protector was originally the idea of another Norwegian company and started out as a collaborative project, but the Kongsberg Group soon took command and developed a functional product by using its systems integration capabilities. Building a plant in Johnstown, Pennsylvania, was part of the deal with the U.S. Army. Protector turned out to be exceptionally profitable. It differed from the other two major defense projects in being developed much more rapidly. It showed the Kongsberg Group's increasing capacity to take on large and complex development projects, though it also involves competences sourced from other product areas.

These different defense developments all involved making new versions of old productspaths are followed, albeit in constructive and purposefully ambitious ways. In each of these three examples, challenging American markets are targeted or complicated American relationships are pursued. The weapon station won competitive contracts with the U.S. Army. Raytheon had their own air-defense product, so getting them on board with a common Kongsberg Group-designed product demanded not only an excellent product, but one that had clear advantages over Raytheon's own. The naval strike missile was originally developed for the Norwegian market, but in such a way that it was supposed to become a state-of-the-art

43. Øyangen, Moderniseringslokomotivet; Erlandsen, Flygende pingviner.

44. This is covered in Sogner and Petersen, Strategiske samspill, 89-91, 226-241. Interviews with Leif Lindbäck (former director at Ministry of Defense), March 21, 2014, Henry K. Johansen (former senior engineer of the NDRE), May 26, 2014, and Tom Gerhardsen (head of Kongsberg Defense \& Aerospace), January 23, 2013, have been particularly important. Also Sogner, En liten brikke i et stort spill, 138-139.

45. This is covered Sogner and Petersen, Strategiske samspill, 142-148, 169-170, 249-255, $264-266$. Interviews with Jan Erik Korssjøen (CEO of the Kongsberg Group), May 14, 2013, and Egil Haugsdal (head of Protector group), August 14, 2013, have been particularly important. 
product internationally. That it became a realistic contender to be a main missile for Lockheed Martin's joint strike fighter project is proof that the Kongsberg Group was able to reach its ambitious goals.

The process of targeting American markets and American partners reflected deep changes in the Kongsberg Group's orientation. Much of what they previously did was influenced by choices made by NDRE. NDRE worked with Norwegian Defense at large, and Norway collaborated within NATO. Both the air-defense system, designed to perform in a mountainous and long country like Norway, and the naval strike missile, purposefully built to be used on smaller vessels, continued NATO-influenced trajectories where Norway found niches. To direct both these projects to American markets and companies as the Kongsberg Group did in the mid1990s was a radical departure from the perspective of the old pre-1987 Kongsberg Våpenfabrikk company. The product strategies were new and much more clearly articulated and with bigger risks of failure than before. To also take on an outside project like the weapon station and direct it in a similar American direction underlines the purposefulness of this new orientation.

The new Kongsberg situation gradually emerged during the 1990s and had this character: long-term ownership, steady profitability, an influx of state-enabled and national opportunities (maritime as well as defense), and a critical mass of internal competence to accomplish new product strategies. The company built its own competence base, and networked with customers in Norway and abroad, aided by NDRE and Norwegian military expertise. It also exploited the huge opportunities within the Norwegian maritime sector. Technical staffs were expanded, and experienced staff given new roles. From 1988 until 2013, turnover in fixed prices increased sevenfold, while the number of employees increased 5.5 times. The firm's employees held much higher formal qualifications. In 1988, 39 percent of all 2044 employees had an engineering education; in 2013, the equivalent figure was 76 percent out of a much larger total of 7493. In absolute terms, there were more than five times as many engineers in 2013. The Kongsberg Group also outgrew its predecessor, Kongsberg Våpenfabrikk, which had 4661 employees at the end of 1986, just months before it closed down. ${ }^{46}$

The markets identified in the 1990s and early 2000s were on the face of it more difficult and demanded bigger constructive roles from a company that in the past tended to rely on NDRE. Whereas the Kongsberg Group shifted emphasis to defining the market and then constructing the product, Kongsberg Våpenfabrikk sought diversity through many markets with the assistance of technology. ${ }^{47}$ This shift would not have been possible without a strong basis of technical capabilities and path knowledge, and this came with the emergence in the 1990s of the new nation-state-corporate alignment. In the defense area, the Kongsberg Group had deep knowledge of the sector and communicated directly with the Ministry of Defense. In the oil and gas and (to some extent) merchant marine sectors, Kongsberg had intimate knowledge of what kind of opportunities would open up with the shift from platform production to new and cheaper systems. With the new process of European integration going on, adapting on the basis of this Hydro ownership model fit well as a means to combine opportunities with challenges and deliver better products.

46. Yearly reports, the Kongsberg Group.

47. Interview with Leif Lindbäck (former director at Ministry of Defense), March 21, 2014. 


\section{Conclusion}

The story of Kongsberg Våpenfabrikk/the Kongsberg Group from 1945 until the present day covers two eras of the Norwegian entrepreneurial state. The present-day success of the Kongsberg Group can hardly be understood without including the creation both of its product base and its national institutional setting. Giving rise to an IT-dominated corporation during the decades up to the 1980s was an entrepreneurial undertaking on several levels. One can quite plausibly argue that it demanded more effort, and more complicated thinking, than bringing about the commercial success of the 2000s.

Yet the impact and intricacies of an entrepreneurial function for the state from the 1990s should not be underestimated. While the commencement of the modernization policy from the 1940s onward was brash, pushy, confident, and at times loud, after the reorganization shock of 1987 and the clear hands-off ideology of the times, being entrepreneurial in the 1990s demanded restraint. The Ministry of Industry—-the majority shareholder-had to be careful to not interfere in what from 1993 onward was officially a private company. It could not communicate with the Ministry of Defense, facilitator of pro-Norwegian defense industry policies. The two ministries thereby opened up for long-term considerations in general and bold marketing efforts within defense. Steeped in the era before the advent of the single EU market and its nondiscriminating policies, the Kongsberg Group's management full well understood the logic of Norwegian oil and gas sector. They exploited opportunities that had been created to a great degree in the previous period, not least by state initiatives that had also affected the company and facilitated the right kind of technological competence. Protecting the various paths of the past meant finding a delicate balance, the state-a many-headed passive creature - sought to give a national company room both to expand at home and to find new markets abroad.

Although this paper has not explicitly discussed the Kongsberg case within a systems of innovation framework, Kongsberg Våpenfabrikk/the Kongsberg Group has developed and prospered within a Norwegian system of innovation supportive of its activities. Mariana Mazzucato's argument for the importance of bold state investments for the benefit of longterm developments finds support in this case. Arguably, though, the policy implications of this case are difficult to distill. Did the investments in the period up to 1987 pay off compared with alternative uses, or were they just too costly for a small nation? Can we talk of a successful recipe from the post-1987 development that can be replicated-a kind of Kongsberg model in an extension of the Hydro model? Maybe so in the case of Norway or in a similar institutional environment, but it is difficult to replicate something this complex elsewhere; it is a long-term affair that has been going on for more than seventy-five years. Yet we should not underestimate the possibilities the Kongsberg company created together with the soft, post-1987 entrepreneurial state.

For some authors, the beneficial path implications of semiconductor competence were critical to the dynamism, resilience, and corpoate formation of Silicon Valley. The long Kongsberg story is also about path creation, sustenance, and eventually, protection, in and around a company that can be said to have been a national champion twice, under very different state regimes. In the pre-1987 regime, paths were created, but the company was 
not very successful commercially. In the post-1987 regime, paths were protected in a constructive way, and the company became very successful in the international competitive economy. The Kongsberg Group also proved to be successful as an umbrella of older products developed not just in Kongsberg Våpenfabrikk, but also in Simrad, Norcontrol, and Navia. It thus followed and extended established product paths of the past. Following paths has been a gateway to continued product development and market penetration in alignment with the Norwegian state apparatus and well-understood Norwegian markets. In the longer run, such alignments may be in danger of becoming a hindrance for renewal, but so far they seem to have worked productively. Following these paths has also involved a market orientation and the development of a much greater competence base than in the past.

KnUt Sogner is professor of economic history at BI Norwegian Business School. Contact information: BI Norwegian Business School, Oslo, Norway. E-mail: knut.sogner@bi.no.

\section{Acknowledgment}

This paper has developed in various stages and benefited from input from, in particular, Tine Petersen Malonæs, as well as Olav Wicken, Bill Lazonick, Dave Mowery, David Teece, Paul Duguid, Espen Ekberg, and Einar Lie. Eamonn Noonan improved the language.

Bibliography of Works Cited

\section{Books}

Erlandsen, Hans Christian. Flygende pingviner: historien om sjømålsraketten Penguin. Kongsberg: Kongsberg Defense \& Aerospace, 2003.

Fagerberg, Jan, David C. Mowery, and Richard R. Nelson. The Oxford Handbook of Innovation. Oxford: Oxford University Press, 2005.

Grabas, C., and A. Nützenadel. Industrial Policy in Europe After 1945: Wealth, Power and Economic Development in the Cold War. London: Palgrave Macmillan, 2014.

Hanisch, Tore Jørgen, and Even Lange. Veien til velstand: industriens utvikling i Norge gjennom 50 år. Oslo: Universitetsforlaget, 1986.

Lécuyer, Christophe. Making Silicon Valley: Innovation and the Growth of High Tech, 1930-1970. Cambridge, MA: MIT Press, 2006.

Leslie, Stuart. The Cold War and American Science: The Military-Industrial-Academic Complex at MIT and Stanford. New York: Columbia University Press, 1993.

Mazzucato, Mariana. The Entrepreneurial State: Debunking Public vs. Private Sector Myths. New York: PublicAffairs, 2015.

McCloskey, Deirdre Nansen, and Alberto Mingardi. The Myth of the Entrepreneurial State. Great Barrington, MA: American Institute for Economic Research, 2020.

Njølstad, Olav.Jens Chr. Hauge: fullt og helt. Oslo: Aschehoug, 2008.

Njølstad, Olav, and Institutt for energiteknikk. Strålende forskning: Institutt for energiteknikk 1948-1998. Oslo: Tano Aschehoug, 1999. 
Njølstad, Olav, and Olav Wicken. Kunnskap som våpen: Forsvarets forskningsinstitutt 1946-1975. Oslo: Tano Aschehoug, 1997.

Øyangen, Knut E. Moderniseringslokomotivet: 1945-1987. Vol. 2. Oslo: Pax, 2014.

Piore, Michael J., and Charles F. Sabel. The Second Industrial Divide: Possibilities for Prosperity. New York: Basic Books, 1984.

Reve, Torger, and Erik W. Jakobsen. Et verdiskapende Norge. Oslo: Universitetsforlaget, 2001.

Saxenian, AnneLee. Regional Advantage: Culture and Competition in Silicon Valley and Route 128. Cambridge, MA: Harvard University Press, 1994.

Sogner, Knut. En liten brikke i et stort spill: den norske IT-industrien fra krise til vekst 1975-2000. Bergen: Fagbokforlaget, 2002.

—. Fra plan til marked: staten og elektronikkindustrien på 1970-tallet. TMV Report Series, vol. 9. Oslo: TMV-senteret, 1994.

—. God på bunnen: Simrad-virksomheten 1947-1997. Oslo: Novus, 1997.

Sogner, Knut, and Tine Petersen. Strategiske samspill: Kongsberg Gruppens historie 1987-2014. Vol. B.3. Oslo: Pax, 2014.

Thune, Taran, Ole Andreas Engen, and Olav Wicken. Petroleum Industry Transformations: Lessons from Norway and Beyond. 1st ed. Routledge Studies in Energy Transitions, vol. 1. Milton: Milton: Routledge, 2019.

Wang, Thor. RA i skuddlinja: industriutvikling og strategiske veivalg gjennom 100 år. Raufoss: T. Wang, 1996.

Wicken, Olav. Norske våpen til Natos forsvar: norsk militærindustri under Koreakrigens opprustning. Vol. 1. Oslo: Institutt for forsvarsstudier, Forsvarsstudier, 1987.

\section{Articles and Chapters}

Christensen, Sverre A. “Statlig eierskap og nasjonal kontroll.” In Kapitalistisk demokrati? Norsk næringsliv gjennom 100 år, edited by Sverre A. Christensen, Harald Espeli, Eirinn Larsen, and Knut Sogner, 67-148. Oslo: Gyldendal, 2003.

Engen, Ole Andreas, Erlend Osland Simensen, and Taran Thune. "The Evolving Sectoral Innovation System for Upstream Oil and Gas in Norway." In Petroleum Industry Transformations. Lessons from Norway and Beyond, edited by Taran Thune, Ole Andreas Engen, and Olav Wicken,23-39. London: Routledge, 2018.

Foreman-Peck, James. "European Industrial Policies in the Post-war Boom: 'Planning the economic miracle." In Industrial Policy in Europe After 1945. Wealth, Power and Economic Development in the Cold War, edited by Chritian Grabas and Alexander Nützenadel, 13-47. London: Palgrave Macmillan, 2014.

Isaksen, Arne. "Innovation Dynamics of Global Competitive Regional Clusters: The Case of the Norwegian Centres of Expertise.” Regional Studies 43, no. 9 (2009): 1155-1166.

Kenney, Martin, and Urs von Burg. "Technology, Entrepreneurship and Path Dependence: Industrial Clustering in Silicon Valley and Route 128." Industrial and Corporate Change 8, no. 1 (1999): 67-103.

Klepper, Steven. "The Origin and Growth of Industry Clusters: The Making of Silicon Valley and Detroit." Journal of Urban Economics 67, no. 1 (2010): 15-32.

Lange, Even. "Førsteopponentinnlegg, Tore Grønlies Statsdrift." Historisk tidsskrift 10, no. 3 (1991): 406-418.

Lie, Einar. "Context and Contingency: Explaining State Ownership in Norway.” Enterprise \& Society 17, no. 4 (2016): 904-930. 
Midelfart, Karen Helene. “Kongsberg gruppen: i skjæringsfeltet mellom høyteknologi og tradisjon.” In SNF-rapport 43/02. Bergen: Samfunns- og næringslivsforskning, 2002.

Nilsen, Odd-Viggo. "Forsøket på å skape en norsk atomindustri.” In Elektronikkentreprenørene. Studier av norsk elektronikkforskning og -industri etter 1945, edited by Olav Wicken, 202-212. Oslo: AdNotam Gyldendal, 1994.

Overby, Signy. "Etableringen av norsk skipsautomatiseringsindustri." In Elektronikkentreprenørene. Studier av norsk elektronikkforskning og -industri etter 1945, edited by Olav Wicken, 152-177. Oslo: AdNotamGyldendal, 1994.

Ryggvik, Helge. "A Short History of the Norwegian Oil Industry: From Protected National Champions to Internationally Competitive Multinationals.” Business History Review 89, no. 1 (2015): 3-41.

Sabel, Charles, and Jonathan Zeitlin. "Historical Alternatives to Mass Production: Politics, Markets and Technology in Nineteenth-Century Industrialization.” Past \& Present, no. 108 (1985): 133-176.

Sogner, Knut. "The Rise and Fall of State Information Technology Planning—or How Norwegian Planners Became Captains of Industry 1960-1990.” In Information Technology Policy-An International History, edited by Richard Coopey, chapter 11, 264-275. Oxford: Oxford University Press, 2004.

Wicken, Olav. "Vekst og våpen." In Forsvarsstudier. Defence Studies, edited by Rolf Tamnes, 156-186. Oslo: Tanum-Norli, 1984.

Cite this article: Sogner, Knut. "Creating and Protecting Paths: Learning in an Entrepreneurial State.” Enterprise $\mathcal{E}$ Society (2021): 1-20. 